\title{
A.2 Lhan Kar Ma catalogue spells and related texts (ca. $800 \mathrm{CE})^{2}$
}

(Pañcarakșā)

[329] Mahāmāyūrī-vidyā-rājñī

[330] Mahā-sāhasra-pramardana-nāma-sūtra

[331] Mahāpratisarā-vidyā-rājñi

[332] Mahā-śitavana-sūtra

[333] Mahā-mantrānudhārī-sūtra

(Long and short dhāranīs)

[334] Mahā-vajra-meru-śikhara-kūṭāgāra-dhāraṇī

[335] Mahā-maṇi-vipula-vimāna-supratișțhita-guhya-parama-rahasya-kalparāja-nāma-dhāraṇī

[336] Vajra-tuṇụa-dhāraṇī (Vajra-tuṇ̣a-nāma-nāga-samaya)

[337] Vajra-maṇụa-nāma-dhāraṇī-mahāyāna-sūtra

[338] Mahākāruṇika-dhāraṇī

[339] Mahā-megha-vāta-maṇḍala-parivarta-sarva-nāga-hṛdaya-nāma-

mahāyāna-sūtra

[340] Samanta-mukha-praveśa-raśmi-vimaloṣnịiṣa-prabhāsa-sarva-tathāgatahṛdaya-samaya-vilokita-nāma-dhāraṇī

[341] Bodhi-maṇḍālaṃkāra-lakṣa-dhāraṇī

[342] Mahābala(-dhāraṇi)-nāma-mahāyāna-sūtra

[343] Avalokiteśvara-cintā(maṇi)-cakravarti-dhāraṇi

[344] Mekhalā-nāma-dhāraṇī

[345] Jayavatī-nāma-mahā-vidyā-rāja

[346] Agra-pradīpa-dhāraṇi-vidyā-rāja

[347] Amoghapāśa-hṛdaya

[348] Sarva-durgati-pariśodhany-uṣnị̣̄a-vijaya-nāma-dhāraṇī

[349] Tathāgatoṣnịiṣa-uddhṛta-sitātapatrā-aparājitā

[350] Aparimitāyur-dhāraṇi

[351] Sumukha-nāma-dhāraṇi

[352] Avalokiteśvara-cintāmaṇi-cakravarti-dhāraṇī

[353] Vaišālī-praveśa-mahāsūtra

[354] Sapta-vetāḍaka-nāma-dhāraṇī

2 After Herrmann-Pfandt 2008.

Ә Open Access. (c) 2021 Gergely Hidas, published by De Gruyter. (c))BY-NC-ND This work is licensed under the Creative Commons Attribution-NonCommercial-NoDerivatives 4.0 International License. https://doi.org/10.1515/9783110713367-005 
[355] Vimala-nāma-dhāraṇi

[356] Vasudhārā-nāma-dhāraṇī

[357] Jayavatī-nāma-dhāraṇi

[358] Viśeșavatī-nāma-dhāraṇī

[359] Vajrājitānala-pramohanī-nāma-dhāraṇī

[360] Grahamātṛkā-nāma-dhāraṇi

[361] (Dittography for IHan 358)

[362] (Dittography for IHan 360)

[363] Mahā-dhāraṇi

[364] Puṣpakūṭa-nāma-dhāraṇī

[365] Buddha-hṛdaya-nāma-dhāraṇi-dharma-paryāya

[366] Avalokiteśvara-ekādaśa-mukha-nāma-dhāraṇi

[367] Samantabhadra-nāma-dhāraṇi

[368] Karuṇāgra-nāma-dhāraṇī

[369] Kāñcanavatī-nāma-dhāraṇī

[370] Prathita-vegavatī-prabhā-vidyā

[371] Cūḍāmaṇi-nāma-dhāraṇī

[372] Dramị̣a-vidyā-rāja

[373] Mahā-daṇụa-nāma-dhāraṇī

[374] Rucirānga-yaști-nāma-dhāraṇi

[375] Nilāmbara-dhara-vajrapāṇi-kalpa-nāma-dhāraṇī

[376] Dhvajāgra-keyūra-nāma-dhāraṇī

[377] Sarva-tathāgatādhișthāna-hṛdaya-guhya-dhātu-karaṇụa-nāma-dhāraṇīmahāyāna-sūtra

[378] Pratītya-samutpāda-kalpa

[379] Samantaprabhā-vidyā-rājñ̄i

[380] Kuṇ̣aly-amṛta-hṛdaya-caturtha-nāma-dhāraṇi

[381] Aparimitāyur-jñāna-hṛdaya-nāma-dhāraṇī

[382] Candanānga-nāma-dhāraṇī

[383] Buddha-hṛdaya-nāma-dhāraṇī

[384] Mahā-mahīndra-nāma-dhārạī

[385] Vijayavatī-nāma-pratyangirā-dhāraṇī

[386] Hiraṇyavatī-nāma-dhāraṇi

[387] Ratna-mālā-nāma-aparājita

[388] Avalokita-î́vara-mātā-nāma-dhāraṇī

[389] Sarva-buddhāngavatī-nāma-dhāraṇi

[390] Vajra-vidāraṇā-nāma-dhāraṇī

[391] Abhayapradā-nāma-aparājita

[392] Abhiṣecanī-nāma-dhāraṇī

[393] Așța-devī-dhāraṇī 
[394] Cakṣur-viśodhanī-nāma-vidyā-mantra

[395] Avalokiteśvara-Hayagrīva-dhāranī

[396] Tapasvi-nāgarāja-paripụcchā-nāma-dhāraṇī

[397] Ârya-daśa-vajrapāṇi-hṛdaya

[398] Vajrabhairava-hṛdaya

[399] Arśa-praśamani-sūtra

[400] Mārīcī-nāma-dhāraṇi

[401] Așta-maṇụalaka-nāma-mahāyāna-sūtra

[402] Jāngulī-nāma-vidyā

[403] Sarvāntarāyika-viśodhanī-nāma-dhāranī

[404] Vajrapāṇi-guhya-nāma-așțaka-mantra-vari-vidhi-nāma-dhāraṇi

[405] Mañjuśrī-svākhyāta-nāma-dhāraṇī

[406] Sarva-durgati-pariśodhana-hṛdaya

[407] Jñānolka-nāma-dhāraṇī-sarva-gati-pariśodhani

[408] Parṇaśabarī-sūtra

[409] Preta-jvāla-mukhāśvāsana-bali-vidhi

[410] Șaḍakșara-vidyā

[411] Ṣaṇmukha-nāma-dhāraṇī

[412] Ojaḥ-pratyañjana-nāma-sūtra

[413] Gaṇapati-hṛdaya

[414] Pūjā-megha-nāma-dhāraṇi

[415] Sarva-karmāvaraṇa-viśodhanī-nāma-dhāraṇī

[416] Aparimita-guṇānuśaṃsā-nāma-dhāraṇī

[417] Cora-vidhvaṃsana-nāma-dhāraṇī

[418] Maṇi-bhadra-hṛdaya

[419] Mahāśvāsā-nāma-vidyārāiñ̄i

[420] Balavatī-nāma-pratyangirā

[421] Sarva-roga-praśamanī-nāma-dhāraṇī

[422] Bahu-putra-pratisaraṇa-nāma-dhāraṇī

[423] Devī-mahā-kālī-nāma-dhāraṇi

[424] Jvara-praśamani-nāma-dhāraṇī

[425] Mahā-lakșmī-sūtra

[426] Vighna-vināyaka-sūtra

[427] Așta-mahā-bhaya-tāraṇī-nāma-dhāraṇī

[428] Manii-bhadra-hṛdaya

[429] Kāruṇikārya-jambhala-jalendra-suśan̉kara-nāma-dhāraṇī

[430] Visphoța-praśamanī

[431] Sarva-dharma-mātṛkā-nāma-dhāraṇi

[432] Akṣi-roga-praśamani(-dhāraṇi)-sūtra

[433] Mahā-śrī-dvādaśa-nāma 
[434] Sahasrāvarta-nāma-dhāraṇī

[435] Mahākāla

[436] Mañjuśrī-bhațțāraka-prajñā-buddhi-vardhana-nāma-dhāraṇī

(Nāmāșțaśatakas)

[437] Nāmāṣța-śataka

[438] Mañjuśrī-jñāna-sattvasya paramārtha-nāma-saṃgīti

[439] Tārādevī-nāmāṣțaśataka

[440] Avalokiteśvara-nāmāṣțaśataka

[441] Mañjuśrī-nāmāșțaśataka

[442] Jambhala-nāmāșțaśataka

[443] Prajñāpāramitā-nāmāșțaśataka

[444] Tathāgata-nāmāṣțaśataka

[445] Vasudhārā(-devī)-nāmāșța-uttara-śataka

(Stotras)

[446] Acintya-stava

[447] Nirupama-stava

[448] Lokātīta-stava

[449] Stuty-atīta-stava

[450] Paramārtha-stava

[451] Kāya-traya-stotra-nāma

[452] Prajñāpāramitā

[453] (Tathāgata-)Guṇāparyanta-stotra

[454] Sarva-bhayottārā-tārā-devī-stotra

[455] Varṇārha-varṇe bhagavato buddhasya stotre 'śakya-stava-nāma

[456] Buddha-bhagavat-guhya-bhavana

[457] Prasāda-pratibhodbhava-bhagavata-buddhasya stotra-nāma

[458] Śrī-vajradhara-saṃīti-bhagavat(-vairocana )-stotra

[459] Avalokiteśvara-vajrapāṇi-stotra

[460] Avalokiteśvara-karuṇā-stotra

[461] Jambhala-stotra

[462] Vyādhi-pati

[463] Revatī-devī 
(Praṇidhānas)

[464] Mahā-pariṇāma-rāja-sa-mantraka

[465] Sandhi-mālā-mahā-tantra-bodhisattva-mahā-viniścaya-nirdeśān Mahā-maṇi-ratna-kauśalya-nirdeśān mahā-pariṇāma-nāma-rāja

[466] Sarva-bhāva-paripūrṇa

[467] Sarva-gati-paritrāṇa

[468] Vajradhvaja-pariṇāma

[469] Maitreya-praṇidhāna

[470] Bhadracaryā-praṇidhāna-rāja

[471] Praṇidhāna-saptati-nāma-gāthā

[472] Agra-caryā-praṇidhāna

[473] Ratnamālā

[474] Bodhiparamapraṇidhāna

[475] Bodhiparama-anudhṛti

(Mañgalagāthās)

[476] Mahā-mañgala-gāthā

[477] Āśīir-vāda-gāthā

[478] Mañgala-gāthā

[479] Mañgala-nāma-gāthā

[480] Svasti-gāthā

[481] Svasti-nāma-gāthā?

[482] Svasty-ayana-gāthā 